\title{
Appraisal of Attitudes and Utilizations of Information and Communication Technology (ICT) Among Students in Nigerian Universities
}

\author{
Mustapha Abdulhamid ${ }^{1}$, Sufiyanu Dauda ${ }^{2}$ \\ ${ }^{1}$ Federal Science College, Sokoto/ Federal Ministry of Education, Nigeria \\ ${ }^{2}$ Federal Government College, Sokoto/ Federal Ministry of Education, Nigeria \\ E-mail: mustaphaa@gmail.com
}

\begin{abstract}
The study examined the attitude and utilization of information and communication technology among university students. The study adopted descriptive - survey as its design, and a population of one thousand three hundred and seventy seven (1377) students were used for the study out of which three hundred and two (302) were purposively sampled from the Department of Science and Vocational Education of the Faculty of Education and Extension Services, Usmanu Danfodiyo University, Sokoto. Two research instruments were used Students' attitude towards Information and Communication Technology (SAICT) and Information and Communication Technology utilization (ICTU). The instruments were pilot tested using Cronbach alpha and reliability index of 0.93 and 0.77 were obtained. The research found that students have positive attitude towards ICT, it was also found that students utilize ICT for academic purpose, and that students attitude is related to utilization. The study recommends that Science education students should be encouraged by the university to sustain their positive attitude towards ICT by ensuring that the students have easy access to the facilities at every point in time.
\end{abstract}

Keywords: ICT; Attitude; Utilization; Science Education Students and University.

\section{INTRODUCTION}

Technology today has turn the world around, as magnificent as the world is, it has been converted into a global village, it has pave ways for the difficulties encountered years back when the need to access information arise. The entire world is connected technologically in such a way that advancement in technology is felt in every nuke and crannies of the globe. Information and communication technology is a vital tool that helps the world in communicating information that are relevant to the development of the society. According to Chafe (2000), ICT refers to the convergence of Information Technology (IT) and Communication Technology (CT). ICT is the acquisition, processing, storing and disseminating of vocal, pictorial, textual and numerical information by micro - electronic based combination of computers and telecommunication. Many nations of the world have since incorporated ICT into their everyday activities including teaching and learning, Nigeria as nation is not an exception. Nigeria is just about two decades into the embracement of ICT (Nwagu, 2006). However, even with the late embracement of ICT into its system the Nigerian Government has invested a lot in the technological development of the nation.

The Nigerian universities like other universities of the world are centres for teaching and learning as well as research, and none of these can be easily actualized unless ICT facilities are made available and used effectively. ICT is a key tool that is having a revolutionary impact on educational methodology globally (Ekeke \& Mbachu, 2015). However, the impact of the revolution would not be felt if ICT are not fully integrated into the education system to serve as a tool that can enhance the teaching and learning pedagogy. No nation can grow beyond the quality of its teachers (FRN, 2014). Since science education students will eventually become certified to teach science subjects in the nearest future, it is therefore of 
great importance that attention is dully paid to the teaching and learning pedagogy in order to make it competitive. Agboola (2006), is of the opinion that many nations of the world including Nigeria have been forced to reposition their educational system in order to make it competitive.

University students varies from one another in terms of their perception and understanding while some students accept the ICT facilities and use it to boast their academic career others still feel reluctant to accommodate the facilities into their academic pursuit, they use it to surf the internet for as long as they wish but will never seize the opportunity to use it for something beneficial academically.

It is in this regard that this paper seeks to assess the attitude and utilization of ICT among science education students in Nigerian universities.

\section{Statement of the Problem}

Despite the investment in technology by the Nigerian government, and the tremendous efforts made by the university management to make available the ICT facilities, one may still wonder why university students still find difficulty in accepting and utilizing the facilities for academic purpose. Although, students spend quite a lot of time on the internet but very few seize some part of their time to justify timing to better themselves academically. This study therefore focused on the attitude of science education students towards ICT, and what they use the facilities for and at the same time assessed the relationship between their attitude and utilization of the facilities in Usmanu Danfodiyo University, Sokoto.

\section{Research Questions}

The study investigated the attitudes and utilization of ICT among science education students in Usmanu Danfodiyo University, Sokoto. Specifically, the study provided answers to the following questions:

1. What is the attitude of science education students towards ICT?

2. What do science education students utilize ICT facilities for?

\section{LITERATURE REVIEW}

Attitude of students towards ICT determines what they use the facilities for, students vary in term of utilization, and this is attributed to their various perception of the ICT. However, the right attitudes towards ICT by students pave way for its utilization in the right direction and vice versa. The utilization provides feedback which serve as a reinforcement toward the academic performance. This practice of interacting with ICT facilities for academics exposes the students to generate more interest in the technology usage, which in the long run affects their academic performance and give them the desire to use the ICT to try something new and use the acquired knowledge now and later in future.

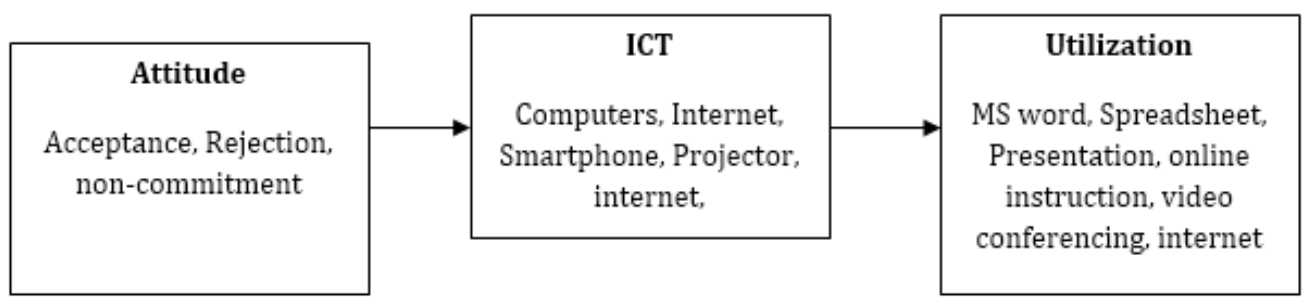

Fig 1: Conceptual framework showing the relationship between attitude and utilization of ICT. 


\section{Concept of Attitude}

The concept attitude has been defined by different scholars in a seemly different ways. Kassin (2008), defines attitudes as relatively enduring beliefs or opinions that predispose people to act in a positive, negative, or ambivalent way to a person, object, or idea. Attitude refers to a person's response to an event either positively or negatively. Attitude as defined by Abdulaziz, Jamaluddin \& Leng (2013), refers to ones judgment about a particular event or subject. This judgement could be positive or negative. Attitude can be learnt or influenced; attitude may also change with experience of the stimulus objects and with social rules or institutions. Victor - Edema (2014), is of the opinion that attitude is within the frame work of social psychology as a subjective or mental preparation for action. Attitude determines what an individual hears, sees, thinks and does. Therefore attitudes are not automatic instead they are sourced from experience. Also, Bello (2009), refers to attitude as a mental predisposition to respond favourably or unfavourably to a particular object or event. Hence science education students' attitude towards Information and communication technology could be positive, negative or ambivalent.

\section{Information and Communication Technology (ICT)}

Information and Communication Technology (ICT) is made up of diverse technological tools that can be used to communicate, disseminate, store, retrieve, and manage information. According to Chafe (2000), ICT refers to the convergence of Information Technology (IT) and Communication Technology (CT). ICT is the acquisition, processing, storing and disseminating of vocal, pictorial, textual and numerical information by micro - electronic based combination of computers and telecommunication. ICT is concerned with the use of technology in handling, acquiring, processing, storing and disseminating information (Bello, 2007). Also Gbadebo, Abimbola, Ademi \& Odupe (2013), see it as a generic term which refers to technologies that are used for collecting, storing, editing and passing information of various forms. Basically ICT is an aggregation of technologies vis-à-vis communication facilities that facilitates and helps to improve the nature in which messages are stored, relayed and disseminated for pre-determined purposes.

The use of Information Communication Technologies has received tremendous attention from both staff and students in Nigerian Universities. ICT offers seemingly infinite access to up-to-date research reports and knowledge (Nwokedi, 2007). Therefore it has become an invaluable tool for learning, teaching and research in Nigerian universities. It has been widely accepted as a channel through which students and researchers communicate in higher institution of learning. There has been positive impact of technological usage on students and researchers in Nigerian universities in their critical thinking, problem solving and networking. Sanni, Awoleye, Egbetokun and Siyanbola (2009), stated that the internet has been applauded as one of the most significant technological development of the $20^{\text {th }}$ century and is seen as tool poised to significantly influence academic research in the nearest future. Its strength lies in the unprecedented growth of the network world wide and its ability to connect computer and several individuals irrespective of their geographical location (Sanni, Awoleye, Egbetokun \& Siyanbola, 2009).

The university as a research institute and a very important body that is relevant in national development must continue to strive to create a suitable learning environment that will give room to students to construct their own knowledge rather than embracing the traditional method. To move the nation forward, the use of Information and Communication Technologies should be encouraged and practiced in Nigerian universities (Nwezeh, 2010). Current information is very useful for the 
development of students in the universities, and this information can easily be obtained through the use of modern technologies, therefore university library will serve as an important infrastructure of the school that could provide such services. However, the technology oriented service has made most university libraries to shift from traditional library services to technologically oriented services, libraries now provide reading resources alongside their online resource or information that are always available on the web. This is significant to the study as the study hoped that students embrace the ICT and make it part of their everyday life. However, some of the most commonly use information and communication technology in the university will be discussed as follows.

\section{ICT Utilization among Students}

Information and communication technologies are electronic technologies used for information storage and retrieval. The emergence of these technologies has shrunk the world into a global village that anyone or organization ignoring it is asking to be side-tracked and placed in the periphery in the international arena. This new technological age is a revolutionary period whose impact is far surpassing those of the agricultural and industrial revolutions. Information has now become the most strategic resources that has transformed the world economy, changed many facets of life, education inclusive. Internet which is one out of the many components of ICT has changed the way we work and interact with each other. The internet has increasingly become an invariable asset in education in terms of learning, teaching and research (Amuoge, \& Ejike, 2016).

The use of internet in the higher institution is an exciting prospect especially when the rugged terrain is the significant impediment to obtain information for the vast majority of people. The world today is information driven and internet has become a key player in education. The need for internet use in tertiary institutions in Nigeria has become very imperative in view of its roles in learning and research. The students cannot ignore the impact of automation and information processing system on their skills and discipline since almost everything within and around their environment are centred on technological innovations. It was observed by Ajala (2007), that the internet has opened up numerous possibilities for doing resource sharing at local and global levels and that information on latest journals, books and discussion can be exchanged directly through the use of Internet services. The use of these technologies is therefore inevitable in our everyday life, especially by the science educators who will always pass the knowledge acquired through the use of technological gadgets unto others. This study like many others also aimed at assessing the level of ICT utilization among science education students.

\section{Review of Related Empirical Studies}

Mbah (2010), conducted a research on the impact of ICT on students' study habits. This is related to the work under study in such a way that it shows concern on the science education students' attitude towards ICT. The study sample was drawn from the department of curriculum studies and teaching CST/Biology in the University of Buea, Cameroun. His findings were that students have positive attitude towards ICT and used the tools to facilitate their learning. Although male students are more favoured to use ICT, students constantly change their study habits based on the type of ICT they use to ease their studies. This study is wider in the sense that in addition to the students study habits, it also looked at students' utilization of ICT and their academic achievement. 
Arthur (2010), investigated the relationship between academic achievement of students and their attitude toward ICT. Eighty four students were drawn from among the undergraduate B. Ed Health science education and postgraduate students of various programmes in the Faculty of Education at the university of Cape coast, Ghana. Attitude scale for computer was developed to assess students' attitude towards computer. The study also adopted the end of semester examination on ICT which consisted of hands on computer exercise in MS-word and SPSS. The result of the analysis revealed that there is moderate correlation between undergraduate students' attitude toward ICT and their achievement in ICT, as the Pearson correlation between undergraduate students attitude towards ICT and their achievement was 0.432 . The study also revealed is a weak correlation between postgraduate students' attitudes towards ICT and their achievement with Pearson correlation of 0.185. However, the general achievement of the undergraduate students and postgraduate students was good as the average score for both categories was $74 \%$ and the standard deviation of the respective category was 15.6 and 10.1 . The study also indicated both set of students showed positive attitudes toward ICT. This study also created a gap by studying only attitude towards ICT and academic achievement leaving ICT utilization by students; it was carried out in Ghana while this study aimed at studying the Nigerian university.

Abdulaziz, Jamaludeen and Haileng (2013), conducted a research that investigated postgraduate students' attitude towards internet and computer use in the year 2011 at university of Malaya in Malaysia. The participants were 289 postgraduate students of university of Malaya. The survey questionnaires were administered to the students who volunteered to be part of the survey. The result of the analysis revealed that postgraduate students showed positive attitude toward computer and internet usage. This was attributed to the availability and accessibility of the internet by the post graduate school of the University of Malaya. The study also revealed that postgraduate students have high attributes towards computer usage as a result of regular use of computer and the internet in instructions, homework and relevant task that required computer usage. The study above failed to study academic achievement alongside attitude and internet usage among postgraduate students of university of Malaya, Malaysia. While the ongoing study focus on all the three variables among undergraduate students in Nigeria.

Nwezeh (2010), examined the level of awareness and usage of internet among staff and students of Obafemi Awolowo University Ile-Ife. This study gathered information from both staff and students by the use of questionnaire. A total of 100 staff and 300 students were randomly selected for the study. Ninety nine and 279 questionnaires were returned by the staff and students respectively. The data was analyzed using simple descriptive statistics. The result from the study showed that $50.5 \%$ of the students and $70.7 \%$ of staff are aware of the internet facilities provided by the university. It also revealed that $50 \%$ of the staff as well as $56 \%$ of the students use the internet as their source of information for research. The study concluded that the use of ICT is gaining momentum in Nigerian universities as the internet is used by both staff and students in sourcing information, and once these facilities are effectively utilized, it will facilitate development and the rate at which information flow will improve. The study created a gap in the area of attitude of students towards ICT as well as academic achievement, which the ongoing study aimed to cover using the undergraduate students of Usmanu Danfodiyo University, Sokoto

Ogedebe (2012), examined the extent and purpose of internet usage among Nigerian university undergraduate students and researchers. Questionnaire were designed and administered to students in the department of Accountancy and Microbiology in the University of Maiduguri, Nigeria. A total of 350 students were selected and responded to the questionnaires and returned the questionnaires. He found 
that $45 \%$ of the university students use the internet for academic purpose. It indicated that they use the internet to search for relevant academic materials, though some few students used the internet to send and receive emails. He also found that about $60 \%$ of the total respondent used the internet facilities regularly. It also indicated that internet usage has influence academic performance of the students with $79 \%$ of the respondents in support of the improvement in their academic performance as a result of ICT usage. It was therefore concluded that a strong relationship exists between the rate at which students use the internet facilities and their academic performance this was indicated by correlation coefficient of 0.57 at 0.05 significance level a strong positive correlation. The study concluded that there is a positive relationship between internet usage and students academic performance. The study above was limited the internet usage and academic performance of students at the university of Maiduguri, it failed to look at the attitude of students towards the internet, which is the concern of ongoing study in addition utilization and academic achievement of students in Usmanu Danfodiyo University, Sokoto.

Chukwudi and Godspower (2015), investigated the role of ICT on University of Benin undergraduate students academic performance. The study used questionnaires which were distributed among 100 students both full time and part- time students. The survey includes male and female undergraduate students from diverse age bracket and faculties in the University of Benin. A total of 93 questionnaires were returned and data were analyzed using the statistical packages for social sciences (SPSS) 16.0 software. The percentages of the responses were also calculated. The study revealed that there was $100 \%$ technological usage, with the new generation of mobile phones called smart phone, the respondents are capable of sending emails, files and multimedia at an amazing speed, through the mobile phones, laptop, Ipad and desktop.

The study also found that $83.9 \%$ of the students of the university visit social network sites on a regular basis. Other sites such as chat engine, entertainment site and adult sites were also visited. It was also revealed by the study that $60.9 \%$ of the students in addition to the social network also surf academic related sites. The study also revealed that $6 \%$ of the students could make a first degree, $31 \%$ second class upper, $43 \%$ second class lower and $20 \%$ third class degree. The study affirmed that ICT have less influence on students academic performance. Though, it seems to have a profound impact on the process of learning in higher education by offering new possibilities for students and researchers. However, with the recent proliferation of ICT tools and services, students are finding it difficult to curtail its negative appeal. This study was also limited to ICT usage in connection with academic achievement in the University of Benin, it failed to look at the attitude towards it, which should be the determinant for its usage.

Amuoge and Ekijke (2016), examined internet awareness and use by the undergraduate students in college of Agriculture and Science Education, Michael Okpara University of Agriculture, Umudike, Abia State, Nigeria. It sought to find out their level of internet awareness, frequency of internet use, purpose of internet use, impact derivable from the internet use and factors affecting their usage of internet. A descriptive survey design was used for the study with a population of 1800 undergraduate students. Sample size of 360 of the population was used for the study. The instrument for data collection was structured questionnaires. Percentages and frequency tables were used in analyzing the data. The result of the study revealed that all the 224 respondents responded positively with regards to being aware of the internet. It also revealed that $76.8 \%$ of the respondents make use of the internet more frequently. The study also found that $52.7 \%$ use the internet mainly for learning purposes, while use it for chatting, sending emails among others. he result of the study revealed that all the 224 respondents responded positively with regards to being aware of the internet. It also revealed that $76.8 \%$ of the respondents 
make use of the internet more frequently. The study also found that $52.7 \%$ use the internet mainly for learning purposes, while use it for chatting, sending emails among others. The result however, showed self-assessed impact of the internet on the students' academic performances. $73.2 \%$ of the respondents claimed that the internet has exercised very high level of impact on them while $23.2 \%$ of the respondents agreed that the impact is low. The study concluded that the potentials of internet awareness and its use in education system and in the life of students can never be overemphasized as it gives quick access to numerous and varied information on net which is a vital ingredient needed by every student in all academic endeavor. This work could not incorporate students attitude towards the ICT, which is another gap been created by the study and the ongoing study aimed at bridging the gap

Yusuf (2011), also examined the attitude of student-teachers attitude towards the use of ICT, competence of student-teacher in the use of ICT and the influence of gender on student-teachers competence and attitude towards ICT. A total of 500 student-teachers were randomly selected for the study from five departments of the faculty of education, university of Ilorin, Ilorin, kwara state, Nigeria. The students comprises of undergraduate student-teachers enrolled into various concurrent teacher education programmes, the students were stratified into male and female. 500 questionnaires were administered to randomly selected student-teachers, 407 were returned, out of which 25 were discarded due to incomplete data and only 382 was found usable as a returned and usable rate of $76.40 \%$. the responses from the students were tabulated and compared, descriptive analysis was carried out and chi-square was also use to analyze the data.

The result of the analysis revealed that student-teachers generally have positive attitude towards ICT, with over $50 \%$ of the students responding in that respect, the student-teachers believe that ICT could generally provide better learning experience. The study also showed that over $50 \%$ of the respondents are competent and have confidence in using the computer and other ICT facilities, and about $25 \%$ of the respondents noted that they had occasionally used these facilities but need further training. The study also indicated that there is no significant difference between male and female student-teachers attitude towards ICT. It also revealed that no significant difference was established between the male and female student-teachers with the male student-teachers having the mean values 2.46 and 2.58 respectively, and the female student-teachers had 2.21 and 2.38 respectively at 0.05 level of significant. The study therefore affirmed that student-teachers have positive attitude toward ICT usage. It also confirmed that gender had no influence on the attitude of student-teachers towards ICT and similarly no significant difference was established between male and female student-teachers in their ICT competence. The study only focuses on attitude of students towards ICT, not considering utilization and academic achievement.

Odogwu and Mbah (2015), sought to determine the level of utilization of ICT by mathematic teachers, their attitude towards the ICT and competence in ICT use. Gender influence on their attitude and competence was also examined. The study adopted 310 participants randomly selected; they were 212 male and 98 female mathematics teachers in surulere local government area of Lagos state, Nigeria. The result of the analysis revealed that $80 \%$ of the participants uses ICT and use it for academic purpose. The study further indicated that majority of the mathematic teachers $83 \%$ do not lack skills in various ICT applications needed to enhance teaching and learning. Over 50\% of mathematic teachers are competent in the use of spreadsheet, presentation, locate and run programmes, download files from internet among others.

The study also revealed the existence of significant difference on mathematic teachers' attitude towards ICT, as the $\mathrm{t}$-value was found to be statistically significant with 12.714 greater than $\mathrm{t}$-tabulated 
Appraisal of Attitudes and Utilizations of Information and Communication Technology (ICT) Among Students in

Nigerian Universities

Mustapha Abdulhamid, Sufiyanu Dauda

1.96 at 0.05 level of significant. It indicated that male and female mathematics teachers do not have same attitude towards ICT. Female teachers had more positive attitude than male teachers. The study concluded that significant difference exist between male and female mathematics teachers in their competence in use of ICT. It also affirmed that female mathematic teachers were more competent than $n$ male mathematic teachers. The study focused on attitude and utilization of ICT by mathematics teachers, while the ongoing study is interested in attitude, utilization and academic achievement of pre-service science teachers and male mathematic teachers. The study focused on attitude and utilization of ICT by mathematics teachers, while the ongoing study is interested in attitude, utilization and academic achievement of pre-service science teachers. $n$ male mathematic teachers. The study focused on attitude and utilization of ICT by mathematics teachers, while the ongoing study is interested in attitude, utilization and academic achievement of pre -service science teachers.

\section{METHOD}

The design adopted by the study was a descriptive survey type. The survey involved the use of questionnaires to collect information from science education students of the Department of Science and Vocational Education, Faculty of Education and Extension Services, Usmanu Danfodiyo University, Sokoto on their attitude toward ICT and its utilization.

The population of the study cut across the one thousand three hundred and seventy seven (1377) students in the Department of Science and Vocational Education of the Faculty of Education and Extension Services of the Usmanu Danfodiyo University, Sokoto and a sample size of three hundred and two (302) students were purposively drawn for the study, the students comprised of various levels ranging from 200, 300 and 400 level.

\section{Research Instruments}

Two instruments were used for this study, the instrument on students' attitude to ICT (SAICT) was adapted from Bello (2009), and a self designed instrument ICT utilization (ICTU) respectively. The SAICT and ICTU have 25 - items and 20 - items questionnaires respectively. The instruments were validated by experts in the field of education and it was pilot tested using cronbach alpha to obtain reliability index of 0.93 and 0.77 respectively.

\section{RESULT AND DISCUSSION}

\section{Research Question One: What is the attitude of Science education students towards ICT?}

Table 1: Attitude of Students towards Information Communication Technology

\begin{tabular}{lllll}
\hline S/N & Students' attitude & Score range & Mean & Std. deviation \\
\hline 1. & High positive attitude & $90-120$ & 106.67 & 9.72 \\
2. & Low positive attitude & $60-89$ & 86.11 & 6.37 \\
3. & Negative attitude & $30-59$ & 46.25 & 3.96 \\
& Total & & 96.68 & 8.72 \\
\hline
\end{tabular}

Source: Research Survey (2017)

Table 1 presents data on attitude of student - teachers to ICT, the results shows that students with high positive attitude have the highest mean score of 106.67 and SD of 9.72, students with low 
positive attitude have a mean score of 86.11 and SD of 6.37 and students with negative attitude have a mean score of 46.25 and SD of 3.72. Generally the average mean score of student's attitude is 96.68 , this therefore implies that students have high positive attitude towards ICT. This finding answer research question one that is science education students in Usmanu Danfodiyo University have positive attitude towards ICT.

Research Question Two: What do science education students utilize ICT facilities for?Table 2: Students' Utilization of Information and Communication Technology

\begin{tabular}{llll}
\hline ITEM & & FREQUENCY & PERCENTAGE \\
\hline 1. & Academic only & 199 & 65.2 \\
2. & For sending and receiving messages only & 35 & 11.5 \\
3. & Social media & 68 & 22.3 \\
TOTAL & 302 & $100 \%$ \\
\hline
\end{tabular}

Source: Research survey (2017)

From the result of Table 2 science education students use the ICT facilities mainly for academics, as the greater percentage of $65.2 \%$ used ICT for academics, while the remaining $33.8 \%$ was shared among the science education students who use ICT, $11.5 \%$ for sending and receiving messages, $22.3 \%$ used it to access social media. This finding revealed that pre-service teachers use ICT facilities for academic purpose.

\section{Null Hypothesis}

There is no significant relationship between attitudes of science education students towards ICT and its utilization.

To test this hypothesis, data generated for the study was analyzed using Spearman rank order correlation coefficient, and the result is shown in Table 3.

Table 3: Relationship between Students' Attitude towards ICT and its Utilization.

\begin{tabular}{lllllll}
\hline Variables & $\mathrm{N}$ & Mean & STD & Rho & P - value & Decision \\
\hline Attitude towards ICT & 302 & 96.68 & 8.72 & & & \\
& & & & 0.68 & 0.04 & Significant \\
ICT Utilization & 302 & 38.26 & 3.46 & & & \\
\hline
\end{tabular}

$\alpha=0.05$ : Source: Research Survey (2017)

From the result of Table 3, students' attitude towards ICT and its' utilization were positively related and significant, $p=0.04$. This indicates that there was significant relationship between students' attitude towards ICT and its utilization, because $p$ value was less than $\alpha$ value of 0.05 level of significance. Therefore the hypothesis which states that there is no significant relationship between attitude of science education student towards ICT and its utilization was rejected.

It was found that student - teachers have positive attitude towards ICT. This finding was in line with Arthur (2010), who found that postgraduate and undergraduate students of Health Science Education in Cape Coast University have positive attitude towards ICT. This finding was also in conformity with Abdulaziz, Jamaludeen and Haileng (2013), who found that postgraduate students of Malaysian university have positive attitude towards ICT. Yusuf (2011) also found that students - teacher 
generally have positive towards ICT. The students' attitude could be attributed to the availability and accessibility of the facilities in the university.

This study also found that students used ICT for academic purpose. Though they also use it for other purposes, but majority of them used it for academics. This finding agrees with Chang and Fang (2007),who found that students uses the internet to search for relevant information on their academics alongside making friends, online shopping among others. Also, Ogedebe (2012) found that students use ICT for academic purpose. The students' utilization of ICT for such purpose could not have been possible, if the facilities are not within the reach of the students in the university. However, the students' positive attitude towards the facilities was also a contributing factor that influences the use of ICT in the right direction.

The study also found significant relationship between attitude towards ICT and its utilization. This was in line with Gao (2005) who found that the students' attitude towards ICT correlates positively with its utilization. It also agrees with Liaw (2002), who reiterated that success of internet utilization was very much related to the users' attitude towards it. Bello (2009), was also in favour of this finding as he found correlation between students' attitude and ICT utilization. The use of ICT facilities therefore depend so much on the users' attitude. If a user has a negative attitude towards it, he uses it for less important and less relevant purpose, and when one has positive attitude, it would be expected that he uses the facilities for relevant academic purpose, even though researches have shown that they can be used for other purposes. However, a positive attitude will facilitate utilization in the right direction.

\section{CONCLUSION}

It was concluded in this paper that students have on the average a high positive attitude towards Information and Communication Technology. Students utilized the facilities for academic purpose, even though they utilized it for other purposes. Students' attitude thus plays the determinant role in the utilization of ICT among students.

\section{RECOMMENDATIONS}

Based on the findings of the study, the following recommendations were made:

1. Science educations students should be encouraged by the university to sustain their positive attitude towards ICT by ensuring that the students have easy access to the facilities at every point in time.

2. The university should make available facilities as technology evolves and create easy access to those facilities in order to sustain students' attitude towards ICT which will in turn aid students' utilization for high academic performance.

\section{REFERENCES}

Abdulaziz, N.,Jamaludeen, S.,\& Haileng, C. (2013). Measuring attitude toward computer and internet usage among postgraduate students in Malaysia. The Turkish Online Journal of Educational Technology, 12(2), 200-216.

Agboola, A. K. (2006). Assessing the awareness and perception of academic staff in using e- learning tool for instructional delivery in a post-secondary institution: A case study. The Public Section Innovation Journal, 11(7), 23-26. 
Ajala, I. O. (2007). Internet awareness, accessibility and use by undergraduate and postgraduate students in Nigerian universities: A Case study of Lautch, Ogbonwo. Nigeria Information Technologist, 4(2), 147-162.

Amuoge, D. A \& Ejike, U . I (2016). Assessment of internet awareness and use by the undergraduate students of college of agricultural and science education in Michael Okpara universityof agriculture, Umudike. American Journal of Educational Research, 4 (2), 200-203.

Arthur, K. A (2010). Relationship between students' attitudes toward ICT and their achievement in ICT at the university of Cape Coast. International Journal of Basic Education, 1, 74-80

Bello, M. R (2007). Postgraduate students accessibility to and utilization of Information And Communication Technology (internet). Sokoto Educational Review, 9 (2), 85-93.

Bello, M. R (2009). A study of science education students' attitude and utilization of Information and communication technology in Federal University of Technology, Minna Unpublished Masters' dissertation, Usmanu Danfodiyo University, Sokoto.

Chafe, A. I. (2000). Using information and communication technologies in the teaching and learning of mathematics. Reading in Education, 3(13), 178-193.

Chan, K., \& Fang, W. (2007). Use of internet and traditional media among young people. Young Consumers, 8(4), 244-256.

Chukwudi, T.A, \& Godspower, O.E (2015). ICT social services and students' academic perfomance. $A$ Multidisciplinary Journal Publication of the Faculty of Science, Adeleke University, Ede, Nigeria, 2 (2), 29 - 46.

Ekeke, J .T , \& Mbachu, C. E ( 2015). The place of ICT in teaching/learning in Nigeria tertiary institutions. American journal of Educational Research 3, 340 - 347.

Federal Republic of Nigeria (2014), National Policy of Education. NERDC Press, Lagos.

Gao, Y (2005). Applying the technology acceptance model to educational hypemedia. A field study. Journal of Educational Multimedia and Hypermedia, 14 (3), 237 - 247.

Gbadebo, A.D., Abimbola, O.C., Ademi, T.S.,\& Odupe, T.A (2013). Extent of teachers awareness, gender and utilization of ICT tools for effective teaching of mathematics In Epe local government of Lagos state. $\quad$ South - West Journal of Teacher-Education, 5 (12), 136-148.

Liaw, S.S (2002). A n internet survey for perceptions of computers and the world wide web; Relationship, prediction and difference. Computer in Human Behavior, 18, 17-35.

Mbah, T. B (2010). The impact of ICT on students' study habits. Case study: University of Buea, Cameroon. Journal of Science and Technology Education Research, 1(5), 107 - 110.

Nwagwu, W.E. (2006). Integrating ICTs into the globalization of the poor developing countries. Information Development, 22 (3), 167-179.

Nwezeh, M. T (2010). The use of information and communication technology (ICT) in Nigerian universities: A Case study of ObafemiAwolowoUniversity, Ile-Ife. Library Philosophy and practice.

Nwokedi, V.C (2007). Impact of internet use on teaching and research activities of the academic Staff of faculty of Medical Sciences, University of Jos: A case study. Gateway Library Journal, 10(1), 13 22. 
Appraisal of Attitudes and Utilizations of Information and Communication Technology (ICT) Among Students in Nigerian Universities

Mustapha Abdulhamid, Sufiyanu Dauda

Odogwu, H. N \& Mbah, S (2015) Attitude and competence of mathematics teachers to the Information and communication technology (ICT) use. Proceeding of Mathematical Association of Nigeria (MAN) Annual National Conference Sept, 2015, 16-27.

Ogedebe, P.M. (2012) Internet usage and students' academic performance In Nigeria tertiary institutions: A Case study of university of Maiduguri. Academic Research International, 2(3), 334-343.

Sanni M, Awoleye O. M, Egbetokun A. A, \& Siyanbola W. O. (2009). Harnessing the Potentials of Internet Technology for Research and Development among Undergraduates in Nigeria: A Case Study of Obafemi Awolowo University. International Journal of Computing And ICT Research, 3(1), 10-17.

Victor-Edema, U.A (2014). Teachers' Attitude Towards Delivering Mathematics Instruction in Senior Secondary School. Journal of Issues on Mathematics, 16(11), 111-119.

Yusuf, M.O (2011). Student - Teachers' Competence and Attitude towards Information and Communication Technology: A Case Study in a Nigerian University. Contemporary Educational Technology, 2011, 2(1), 18-36 18. 